\title{
PENGARUH MINAT BELAJAR DAN KEDISIPLINAN TERHADAP PRESTASI BELAJAR PAI
}

\author{
Muhamad Ishak, ${ }^{*}$ \\ Syahidin, Saepul Anwar \\ Program Studi Ilmu Pendidikan Agama Islam, \\ Fakultas Pendidikan Ilmu Pengetahuan Sosial, Universitas Pendidikan Indonesia \\ *Email:muhamad.ishak@student.upi.edu
}

\begin{abstract}
ABSTRAK
Permasalahan belajar siswa saat ini sering dihadapkan dengan berbagai masalah kompleks, di antaranya minat belajar dan kedisiplinan siswa. Dampak negatif apabila dibiarkan masalah ini menyebabkan tujuan dari setiap pembelajaran tidak akan tercapai dan efeknya prestasi belajar siswa menjadi rendah. Hal ini tentunya perlu mendapatkan perhatian dari kita semua, khususnya pendidik. Oleh sebab itu, mengetahui kondisi psikologis peserta didik sangat diperlukan dalam proses pembelajaran di kelas. Hal ini bermanfaat agar materi yang disampaikan oleh pendidik dapat dipahami peserta didik sehingga peserta didik dapat mencapai tujuan pembelajaran. Selain itu, suasana dalam kelas yang kondusif mendukung untuk pembelajaran di kelas. Oleh karena itu, tujuan dari penelitian ini adalah untuk mengetahui pengaruh minat belajar dan kedisiplinan terhadap prestasi belajar PAI. Penelitian dilaksanakan di SMA Negeri 7 Bandung. Penelitian ini menggunakan pendekatan kuantitatif dengan metode deskriptif. Data penelitian diambil menggunakan angket minat belajar dan kedisiplinan, serta nilai PAI dalam raport semester ganjil untuk melihat prestasi belajar PAI. Teknik analisis data yang digunakan adalah regresi ganda. Hasil penelitian menunjukkan bahwa ada pengaruh antara minat belajar dan kedisiplinan terhadap prestasi belajar PAI pada siswa kelas XI SMA Negeri 7 Bandung. Hasil uji regresi diperoleh $\mathrm{R}=0,244$ yang berarti minat belajar dan kedisiplinan berpengaruh terhadap prestasi belajar PAI sebesar 5,95\%, dan sisanya 94,05\% dipengaruhi oleh faktor lain yang belum ditemukan dalam penelitian ini. Kesimpulannya, dalam penelitian ini tidak ada pengaruh signifikan antara minat belajar dan kedisiplinan terhadap prestasi belajar PAI pada siswa kelas XI SMA Negeri 7 Kota Bandung.
\end{abstract}

Kata Kunci: Kedispilinan, Minat Belajar, Prestasi Belajar PAI. 


\section{PENDAHULUAN}

Dalam Undang-Undang Sistem Pendidikan Nasional Nomor 20 tahun 2003 Bab II Pasal 3 mengenai tujuan pendidikan nasional, yaitu : Pendidikan nasional berfungsi mengembangkan kemampuan dan membentuk watak serta peradaban bangsa yang bermartabat dalam rangka mencerdaskan kehidupan bangsa, bertujuan untuk berkembangnya potensi peserta didik agar menjadi manusia yang beriman dan bertakwa kepada Tuhan Yang Maha Esa, berakhlak mulia, sehat, berilmu, cakap, kreatif, mandiri dan menjadi warga Negara yang demokratis serta bertanggung jawab.

Agar berkembangnya potensi peserta didik untuk menjadi manusia yang beriman dan bertakwa kepada Tuhan Yang Maha Esa serta berakhlak mulia, maka dalam hal ini perlu pendidikan agama. Dalam Undang-Undang Nomor 20 tahun 2003 Bab X kurikulum Pasal 37 ayat 1 dan 2 butir a, menegaskan bahwa kurikulum pendidikan dasar dan menengah sampai perguruan tinggi wajib memuat pendidikan agama.

Dalam kurikulum nasional, mata pelajaran PAI merupakan mata pelajaran PAI wajib di sekolah sejak TK sampai SMA/SMK, sedangkan mata kuliah PAI merupakan mata kuliah wajib di perguruan tinggi. Materi agama Islam di sekolah diberi nama mata pelajaran Pendidikan Agama Islam (PAI), bukan Pengajaran Agama Islam karena pengajaran hanya sebatas transfer pengetahuan dari guru kepada murid yang akan menghasilkan siswa berpengetahuan agama secara mendalam, padahal materi pelajaran PAI sudah sepatutnya disampaikan melalui proses pendidikan yang dilaksanakan secara utuh, menyeluruh, dan berkesinambungan. Jadi, sudah seharusnya diberi nama pendidikan karena cakupannya lebih luas dan esensi dari pendidikan, yaitu pewarisan pengetahuan (transfer of knowledge), pewarisan budaya (transfer of Culture), dan pewarisan nilai (transfer of value). Dari uraian di atas, maka dapat dipahami bahwa materi agama Islam di sekolah diberi nama Pendidikan Agama Islam karena lebih menitikberatkan kepada pembinaan akhlak siswa. (Syahidin, 2009, hlm. 1-3)

Namun, kenyataannya muncul beberapa pendapat yang mengkritisi Pendidikan Agama di sekolah, di antaranya : Dalam Mimbar Pendidikan, No. 1 tahun XIX, 2000 (Majid \& Andayani, 2006, hlm. 165) hasil belajar PAI di sekolah-sekolah belum sesuai dengan tujuan-tujuan Pendidikan Agama Islam. Sedangkan Nurcholis Madjid (Majid \& Andayani, 2006, hlm. 165) berpendapat bahwa kegagalan pendidikan agama disebabkan pembelajaran PAI lebih menitikberatkan pada hal-hal yang bersifat formal dan hafalan, bukan pada pemaknaannya.

Selain pendapat di atas, Departemen Agama (Majid \& Andayani, 2006, hlm. 167-168) mengemukakan ciriciri siswa dan permasalahan yang dihadapinya pada sekolah umum: 1) kemampuan siswa heterogen; 2) waktu (jam pelajaran) yang terbatas; 3) minat siswa lebih besar pada mata pelajaran lain; dan sarana dan prasarana PAI yang terbatas.

Hal ini terbukti ketika peneliti melakukan studi pendahuluan, peneliti melakukan wawancara dengan salah satu guru PAI yang ditunjuk oleh wakil kepala sekolah bidang kurikulum, mengenai permasalahan PAI yaitu beban belajar yang harus ditempuh siswa banyak sehingga siswa sering pulang sekolah sore dan menyebabkan antusias belajar siswa menurun, selain itu kedisiplinan siswa semakin menurun.

Adapun fakta lainnya yaitu siswa kelas XI yang telah di tes secara acak mengenai materi yang telah di pelajari, hasilnya masih terdapat siswa yang belum menguasai/memahami materi yang sudah diajarkan, sedangkan untuk tes baca AlQur'an, terdapat siswa yang belum bisa membaca Al-Qur'an. 


\section{KAJIAN PUSTAKA}

\section{Minat Belajar}

Minat adalah kecendrungan seseorang untuk menyukai objek-objek atau kegiatan-kegiatan yang membutuhkan perhatian dan menghasilkan kepuasan (Kebudayaan, 2013, hlm. 20). Minat berarti kecenderungan dan kegairahan yang tinggi atau keinginan yang besar terhadap sesuatu (Syah, 2011, hlm. 133). Selain itu, minat juga dapat diartikan sebagai rasa tertarik yang ditunjukkan oleh individu kepada suatu objek, baik objek berupa benda hidup maupun benda yang tidak hidup (Hadis, 2008, hlm. 44). Adapun menurut Hilgard (Slameto, 2003, hlm. 57) minat adalah kecendrungan yang tetap untuk memperhatikan dan mengenang beberapa kegiatan. Berbeda dengan Hilgard, Slameto (2003, hlm. 180) berpendapat bahwa minat adalah suatu rasa lebih suka dan rasa keterikatan pada suatu hal atau aktivitas, tanpa ada yang menyuruh. Dari pengertian minat yang dikemukakan oleh para ahli di atas, minat mempunyai ruang lingkup yang luas, namun yang dibahas di sini adalah minat belajar. Minat belajar menurut Abdul Hadis (2008, hlm. 44) dapat diartikan sebagai rasa tertarik yang ditunjukkan oleh peserta didik dalam melakukan aktivitas belajar, baik di rumah, di sekolah, dan di masyarakat. Minat belajar yang di maksud dalam penelitian ini adalah rasa tertarik yang ditunjukkan oleh peserta didik dalam melakukan aktivitas belajar pada saat pembelajaran PAI.

\section{Kedisiplinan}

Disiplin berasal dari kata yang sama dengan "disciple," yakni seorang yang belajar dari atau secara suka rela mengikuti seorang pemimpin (Hurlock, 1978, hlm. 82). Menurut E. Mulyasa (2010, hlm. 108), kedisiplinan adalah suatu keadaan tertib dimana orang yang tergabung dalam suatu sistem tunduk pada peraturan-peraturan yang telah ada dengan senang hati. Sedangkan kedisiplinan mempunyai arti dalam nilai untuk pendidikan budaya dan karakter bangsa (Yusuf \& Sugandhi, 2011, hlm. 34) adalah tindakan yang menunjukkan perilaku tertib dan patuh pada berbagai ketentuan dan peraturan. Adapun merujuk pada buku Pedoman Umum nilai-nilai budi pekerti untuk pendidikan dasar dan menengah dirumuskan identifikasi nilai-nilai budi pekerti (Majid \& Andayani, 2012, hlm. 45) di antaranya adalah kedisiplinan, yaitu bila mengerjakan sesuatu dengan tertib; memanfaatkan waktu untuk kegiatan yang positif; belajar secara teratur dan selalu mengerjakan sesuatu dengan penuh tanggung jawab. Jadi, dapat disimpulkan bahwa kedisiplinan adalah peraturan yang diciptakan dan dibentuk dalam sekolah sehingga orang di dalamnya menunjukkan perilaku taat, patuh, teratur, dan tertib.

\section{Prestasi Belajar PAI}

Kata "prestasi" berasal dari bahasa Belanda, yaitu prestatie. Kemudian dalam bahasa Indonesia menjadi "prestasi" yang berarti "hasil usaha". Istilah "prestasi belajar" (achievement) berbeda dengan "hasil belajar" (learning outcome). Prestasi belajar pada umumnya berkenaan dengan aspek pengetahuan, sedangkan hasil belajar meliputi aspek pembentukan watak peserta didik. Kata prestasi banyak digunakan dalam berbagai bidang dan kegiatan, antara lain dalam kesenian, olah raga, dan pendidikan, khususnya pembelajaran (Arifin, 2012, hlm. 12). Dalam hal ini, prestasi belajar PAI yang dimaksud adalah nilai yang di dapat peserta didik dalam raport mata pelajaran PAI yang sudah diajarkan. 


\section{METODE}

Pendekatan yang digunakan dalam penelitian ini adalah kuantitatif yang bersifat non eksperimental dengan menggunakan metode deskriptif. Partisipan yang terlibat dalam penelitian ini adalah guru PAI kelas XI dan siswa kelas XI SMA Negeri 7 Bandung.

Peneliti menjadikan SMA Negeri 7 Bandung sebagai tempat penelitian karena berdasarkan penelitian pendahuluan yang dilakukan peneliti, diperoleh fakta bahwa permasalahan PAI yaitu beban belajar yang harus ditempuh siswa banyak sehingga siswa sering pulang sekolah sore sehingga menyebabkan antusias belajar siswa menurun, selain itu kedisiplinan siswa semakin hari semakin menurun. Populasi dalam penelitian ini adalah siswa kelas XI SMA Negeri 7 Bandung yang berjumlah 387 dengan tiga program, yaitu 6 kelas MIPA, 4 kelas IPS, dan 1 kelas Bahasa.

Teknik penelitian yang digunakan yaitu proportionate stratified random sampling. Teknik ini digunakan bila populasi mempunyai anggota/unsur yang tidak homogen dan berstrata secara proporsional. Teknik ini di ambil karena jumlah siswa kelas XI adalah 387 siswa, yang terbagi dalam tiga program, yaitu 6 kelas MIPA, 4 kelas IPS, dan 1 kelas Bahasa, sehingga jumlah sampel yang di ambil adalah 2 kelas MIPA, 2 kelas IPS, dan 1 kelas Bahasa dan berjumlah 126 siswanya. Data penelitian diperoleh menggunakan angket minat belajar dan kedisiplinan, serta nilai PAI dalam raport semester ganjil untuk melihat prestasi belajar PAI.

\section{HASIL DAN PEMBAHASAN}

Untuk mengetahui ketepatan alat ukur kuesioner, maka dalam penelitian ini perlu dilakukan uji validitas dan reliabilitas. Uji validitas dilakukan secara uji konstrak untuk mengetahui apakah jawaban responden konsisten dan data yang dikumpulkan valid. Sedangkan uji reliabel digunakan apabila angket yang digunakan beberapa kali untuk mengukur obyek yang sama, maka akan menghasilkan data yang sama (konsisten).

Dalam pengujian validitas dan reliabilitas menggunakan aplikasi IBM SPSS 21, Untuk mengetahui tingkat validitas perhatikan angka pada Corrected Item-Total Correlation yang merupakan korelasi antar skor item dengan skor total item (nilai $r_{\text {hitung }}$ ) dibandingkan dengan nilai $r_{\text {tabel. }}$ Jika nilai $r_{\text {hitung }}$ lebih besar dari nilai $r_{\text {tabel }}$ atau nilai $r_{\text {hitung }}>$ nilai $r_{\text {tabel }}$ maka item tersebut adalah valid dengan menggunakan distribusi (Tabel r) untuk $\alpha=0,05$ dengan derajat kebebasan $(\mathrm{dk}=\mathrm{n}-1=156-1=155)$ sehingga didapat $r_{\text {tabel }}=0,157$. Adapun hasil angket minat belajar dan kedisiplinan adalah sebagai berikut.

Tabel 1. Hasil Uji Validitas

\begin{tabular}{|l|l|l|l|l|}
\hline No. & $\begin{array}{l}\text { Minat } \\
\text { Belajar }\end{array}$ & $\begin{array}{l}\text { Kedisipl } \\
\text { inan }\end{array}$ & $r_{\text {tabel }}$ & Ket. \\
\hline 1. & 0,273 & 0,261 & 0,157 & Valid \\
\hline 2. & 0,246 & 0,395 & 0,157 & Valid \\
\hline 3. & 0,202 & 0,402 & 0,157 & Valid \\
\hline 4. & 0,328 & 0,352 & 0,157 & Valid \\
\hline 5. & 0,371 & 0,426 & 0,157 & Valid \\
\hline 6. & 0,421 & 0,175 & 0,157 & Valid \\
\hline 7. & 0,313 & 0,397 & 0,157 & Valid \\
\hline 8. & 0,210 & 0,321 & 0,157 & Valid \\
\hline 9. & 0,208 & 0,254 & 0,157 & Valid \\
\hline 10. & 0,257 & 0,419 & 0,157 & Valid \\
\hline 11. & 0,342 & 0,366 & 0,157 & Valid \\
\hline 12. & 0,299 & 0,341 & 0,157 & Valid \\
\hline 13. & 0,381 & 0,377 & 0,157 & Valid \\
\hline 14. & 0,330 & 0,281 & 0,157 & Valid \\
\hline 15. & 0,261 & 0,469 & 0,157 & Valid \\
\hline
\end{tabular}




\begin{tabular}{|l|l|l|l|l|}
\hline 16. & 0,286 & 0,266 & 0,157 & Valid \\
\hline 17. & 0,323 & 0,303 & 0,157 & Valid \\
\hline 18. & 0,365 & 0,264 & 0,157 & Valid \\
\hline 19. & 0,392 & 0,212 & 0,157 & Valid \\
\hline 20. & 0,416 & 0,436 & 0,157 & Valid \\
\hline 21. & 0,309 & 0,211 & 0,157 & Valid \\
\hline 22. & 0,321 & 0,212 & 0,157 & Valid \\
\hline 23. & 0,161 & 0,185 & 0,157 & Valid \\
\hline 24. & 0,323 & 0,489 & 0,157 & Valid \\
\hline 25. & 0,224 & 0,368 & 0,157 & Valid \\
\hline 26. & 0,281 & 0,181 & 0,157 & Valid \\
\hline 27. & 0,289 & 0,259 & 0,157 & Valid \\
\hline 28. & 0,171 & 0,387 & 0,157 & Valid \\
\hline 29. & 0,251 & 0,268 & 0,157 & Valid \\
\hline 30. & 0,352 & 0,422 & 0,157 & Valid \\
\hline 31. & - & 0,290 & 0,157 & Valid \\
\hline 32. & - & 0,320 & 0,157 & Valid \\
\hline 33. & - & 0,406 & 0,157 & Valid \\
\hline 34. & - & 0,274 & 0,157 & Valid \\
\hline 35. & - & 0,239 & 0,157 & Valid \\
\hline 36. & - & 0,331 & 0,157 & Valid \\
\hline 37. & - & 0,377 & 0,157 & Valid \\
\hline 38. & - & 0,226 & 0,157 & Valid \\
\hline 39. & - & 0,350 & 0,157 & Valid \\
\hline 40. & - & 0,351 & 0,157 & Valid \\
\hline & & & & \\
\hline
\end{tabular}

Tabel 2. Hasil Uji Reliabilitas

\begin{tabular}{|l|c|c|l|c|}
\hline \multirow{2}{*}{$\begin{array}{l}\text { Ketera } \\
\text { ngan }\end{array}$} & \multicolumn{2}{|l|}{$\begin{array}{l}\text { Validitas } \\
\text { Instrumen } \\
\text { Penelitian }\end{array}$} & $\begin{array}{l}\text { R } \\
\text { Kritis }\end{array}$ & $\begin{array}{c}\text { Keteran } \\
\text { gan }\end{array}$ \\
\cline { 2 - 3 } & $X_{1}$ & $X_{2}$ & & \\
\hline $\begin{array}{l}\text { Koefisi } \\
\text { en }\end{array}$ & 0,8 & 0,85 & 0,6 & Reliabel \\
$\begin{array}{l}\text { Reliabi } \\
\text { litas }\end{array}$ & 02 & 7 & & \\
\hline
\end{tabular}

Untuk melakukan analisis regresi berganda diperlukan beberapa persyaratan sebagai berikut:

a. Data Harus berdistribusi normal

b. Tidak terdapat multicolliniearity pada variabel bebas

c. Tidak terjadi heterokedastisitas

d. Tidak terdapat otokorelasi

Uji kenormalan distribusi pada variabel minat belajar $\left(X_{1}\right)$, kedisiplinan $\left(X_{2}\right)$, dan prestasi belajar PAI (Y) dilakukan dengan teknik KolmogorovSmirnov. Untuk memudahkan analisis, peneliti menggunakan aplikasi IBM SPSS 21. Adapun kriteria dalam pengambilan keputusan :

> Jika nilai signifikansi/p-value/Sig. > 0,05 , artinya data normal

$>$ Jika nilai signifikansi/p-value/Sig. < 0,05 , artinya data tidak normal.

Tabel 3. Uji Normalitas Kolmogorov Smirnov Test

One-Sample Kolmogorov-Smirnov Test

\begin{tabular}{|ll|r|}
\hline & & $\begin{array}{r}\text { Unstandardized } \\
\text { Residual }\end{array}$ \\
\hline $\mathrm{N}$ & & 126 \\
Normal & Mean & .0000000 \\
Parameters & a, & Std. \\
b & Deviation & .23517257 \\
Most & Absolute & \\
Extreme & Positive & .102 \\
Differences & Negative & .061 \\
Kolmogorov-Smirnov Z & -.102 \\
Asymp. Sig. (2-tailed) & 1.141 \\
\hline
\end{tabular}

a. Test distribution is Normal.

b. Calculated from data.

Berdasarkan tabel 3 dengan tingkat kepercayaan $\alpha=0,05$ diperoleh nilai signifikansi pada uji Kolmogorov Smirnov Output untuk minat belajar dan kedisiplinan terhadap prestasi belajar PAI sebesar 0,148>0,05. Dengan demikian, data pada sampel berdistribusi normal.

Uji heterokedastisitas ini bertujuan untuk mengetahui seragam tidaknya variansi sampel-sampel yang diambil dari variansi yang sama. Pengujian ini menggunakan aplikasi IBM SPSS 21, didapatkan hasil sebagai berikut. 
Tabel 4 Hasil Uji Heterokedastisitas

Coefficients $^{\mathrm{a}}$

\begin{tabular}{|c|c|c|c|c|c|}
\hline \multirow[t]{2}{*}{ Model } & \multicolumn{2}{|c|}{$\begin{array}{l}\text { Unstandardized } \\
\text { Coefficients }\end{array}$} & $\begin{array}{c}\text { Standardized } \\
\text { Coefficients }\end{array}$ & \multirow[t]{2}{*}{$\mathrm{t}$} & \multirow[t]{2}{*}{ Sig. } \\
\hline & $\mathrm{B}$ & Std. Error & Beta & & \\
\hline (Constant) & .160 & .193 & & .828 & .409 \\
\hline 1 Minat Belajar & .001 & .004 & .035 & .316 & .753 \\
\hline Kedisiplinan & $-2.528 \mathrm{E}-005$ & .002 & -.002 & -.015 & .988 \\
\hline
\end{tabular}

a. Dependent Variable: RES_2

Berdasarkan tabel 4 dapat diketahui bahwa nilai signifikansi variabel minat belajar $\left(X_{1}\right)$ dengan prestasi belajar PAI (Y) adalah $0,753>0,05$, sedangkan variabel kedisiplinan $\left(X_{2}\right)$ dengan prestasi belajar PAI (Y) adalah 0,988 > 0,05. Maka Ho ditolak dan $\mathrm{Ha}$ diterima, dengan demikian dapat disimpulkan bahwa data tersebut terbebas dari heterokedastisitas

Tabel 5. Hasil Uji Linearitas

ANOVA Table

\begin{tabular}{|cll|c|c|c|c|c|}
\hline & & & $\begin{array}{c}\text { Sum of } \\
\text { Squares }\end{array}$ & df & $\begin{array}{c}\text { Mean } \\
\text { Square }\end{array}$ & F & Sig. \\
\hline Prestasi & Between & (Combined) & 1.174 & 21 & .056 & .941 & .541 \\
Belajar & Groups & Linearity \\
PAI * & & .240 & 1 & .240 & 4.046 & .047 \\
Minat & $\quad \begin{array}{l}\text { Deviation } \\
\text { from }\end{array}$ & .933 & 20 & .047 & .786 & .725 \\
Belajar & Linearity & 6.178 & 104 & .059 & & \\
& Within Groups & 7.352 & 125 & & & \\
\hline
\end{tabular}

ANOVA Table

\begin{tabular}{|c|c|c|c|c|c|c|c|}
\hline & & & $\begin{array}{l}\text { Sum of } \\
\text { Squares }\end{array}$ & $\mathrm{df}$ & $\begin{array}{l}\text { Mean } \\
\text { Square }\end{array}$ & $\mathrm{F}$ & Sig. \\
\hline \multirow{5}{*}{$\begin{array}{l}\text { Prestasi } \\
\text { Belajar PAI } \\
* \\
\text { Kedisiplinan }\end{array}$} & Between & (Combined) & 2.234 & 36 & .062 & 1.079 & .377 \\
\hline & Groups & Linearity & .420 & 1 & .420 & 7.296 & .008 \\
\hline & 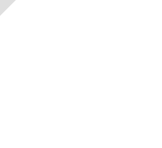 & $\begin{array}{l}\text { Deviation } \\
\text { from } \\
\text { Linearity }\end{array}$ & 1.814 & 35 & .052 & .901 & .626 \\
\hline & Within C & roups & 5.118 & 89 & .058 & & \\
\hline & Total & & 7.352 & 125 & & & \\
\hline
\end{tabular}

Berdasarkan tabel 5 dapat diketahui bahwa minat belajar terhadap prestasi belajar PAI mempunyai nilai Sig. 0,725> 0,05 dan $F_{\text {Hitung }}<F_{\text {Tabel }}(0,786<1,84)$, sedangkan untuk kedisiplinan terhadap prestasi belajar PAI mempunyai nilai Sig. $0,626>0,05$ dan $F_{\text {Hitung }}<F_{\text {Tabel }}(0,901$ $<1,62)$. Maka dapat disimpulkan bahwa 
data tersebut menggunakan model regresi

Uji hipotesis pada penelitian ini menggunakan uji t yang dimaksudkan dan memastikan hasil yang diperoleh dari analisis regresi linear apakah variabel independent berpengaruh atau tidak berpengaruh terhadap variabel dependent. Dalam penelitian ini, kaidah keputusannya adalah:

a. Minat Belajar terhadap Prestasi Belajar PAI

$H_{0}: p=0$, Tidak adanya pengaruh minat belajar terhadap prestasi belajar PAI

$H_{1}: p \neq 0$, Adanya pengaruh minat belajar terhadap prestasi belajar PAI linear.

$H_{0}$ Tolak : apabila angka probalitas $\leq 0,05$

$H_{1}$ Tolak : apabila angka probalitas $\geq 0,05$

b. Kedisiplinan terhadap Prestasi Belajar PAI

$H_{0}: p=0$, Tidak adanya pengaruh kedisiplinan terhadap prestasi belajar PAI

$H_{1}: p \neq 0$, Adanya pengaruh kedisiplinan terhadap prestasi belajar PAI

$H_{0}$ Tolak : apabila angka probalitas $\leq 0,05$

$H_{1}$ Tolak : apabila angka probalitas $\geq 0,05$

Dari hasil analisis menggunakan aplikasi IBM SPSS 21, diperoleh hasil berikut.

Tabel 6. Hasil Uji Hipotesis

\section{Coefficients $^{\mathrm{a}}$}

\begin{tabular}{|c|c|c|c|c|c|c|}
\hline & \multirow[t]{2}{*}{ Model } & \multicolumn{3}{|c|}{ Unstandardized Standardized } & \multirow[t]{2}{*}{$\mathrm{t}$} & \multirow[t]{2}{*}{ Sig. } \\
\hline & & B & Std. Error & Beta & & \\
\hline & (Constant) & 2.570 & .301 & & 8.545 & .000 \\
\hline 1 & Minat Belajar & .003 & .006 & .062 & .577 & .565 \\
\hline & Kedisiplinan & .005 & .003 & .202 & 1.876 & .063 \\
\hline
\end{tabular}

a. Dependent Variable: Prestasi Belajar PAI

Berdasarkan tabel 6, maka dapat di ambil keputusan:

1) Minat belajar terhadap prestasi belajar PAI

a) Berdasarkan probabilitas, hasil yang diperoleh Sig. 0,565> 0,05 artinya tidak adanya pengaruh minat belajar terhadap prestasi belajar PAI siswa kelas XI SMAN 7 Bandung.

b) Berdasarkan pengujian melalui statistik-t, Nilai t hitung adalah sebesar 0,577, sementara $\mathrm{t}$ tabel diperoleh dari $\mathrm{dk}=\mathrm{n}-2$ $(126-2=124)$ dengan taraf signifikansi 5\%, karena $t_{\text {hitung }}<t_{\text {tabel }} \quad(0,577<$ 1,960). Maka Ho diterima artinya tidak terdapat hubungan yang signifikan antara minat belajar terhadap prestasi belajar PAI siswa kelas XI SMAN 7 Bandung.

2) Kedisiplinan terhadap prestasi belajar PAI

a) Berdasarkan probabilitas, hasil yang diperoleh Sig. 0,063> 0,05 artinya tidak adanya pengaruh kedisiplinan terhadap 
prestasi belajar PAI siswa kelas XI SMAN 7 Bandung.

b) Berdasarkan pengujian melalui statistik-t, Nilai t hitung adalah sebesar 1,876, sementara $\mathrm{t}$ tabel diperoleh dari $\mathrm{dk}=\mathrm{n}-2$ $(126-2=124)$ dengan taraf signifikansi 5\%, karena $t_{\text {hitung }}<t_{\text {tabel }} \quad(1,876<$ 1,960). Maka Ho diterima artinya tidak terdapat hubungan yang signifikan antara kedisiplinan terhadap prestasi belajar PAI siswa kelas XI SMAN 7 Bandung.

Besarnya koefisien korelasi antara variabel $X_{1}, X_{2}$, dan $\mathrm{Y}$ dengan menggunakan aplikasi IBM SPSS 21 yang rumus perhitungannya menggunakan rumus koefisien korelasi Product Moment dari Pearson diperoleh output sebagai berikut.

Tabel 7. Hasil Uji Koefisien Korelasi

Correlations

\begin{tabular}{|c|c|c|c|c|}
\hline & & $\begin{array}{l}\text { Minat } \\
\text { Belajar }\end{array}$ & Kedisiplinan & Prestasi Belajar PAI \\
\hline \multirow{5}{*}{$\begin{array}{l}\text { Minat } \\
\text { Belajar }\end{array}$} & Pearson & 1 & $.586^{*}$ & $.181^{*}$ \\
\hline & Correlation & & & \\
\hline & Sig. (2-tailed) & & .000 & .043 \\
\hline & $\mathrm{N}$ & 126 & 126 & 126 \\
\hline & Pearson & $.586^{* *}$ & 1 & $.239^{* *}$ \\
\hline \multirow{3}{*}{$\begin{array}{c}\text { Kedisipli } \\
\text { nan }\end{array}$} & Correlation & & & \\
\hline & Sig. (2-tailed) & .000 & & .007 \\
\hline & $\mathrm{N}$ & 126 & 126 & 126 \\
\hline \multirow{3}{*}{$\begin{array}{c}\text { Prestasi } \\
\text { Belajar } \\
\text { PAI }\end{array}$} & Pearson & $.181^{*}$ & $.239^{* *}$ & 1 \\
\hline & Sig (2-tailed) & 042 & & \\
\hline & $\mathrm{N}$ & 126 & 126 & 126 \\
\hline & 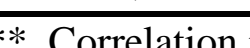 & & & \\
\hline
\end{tabular}
berikut:

Dari tabel 7, diperoleh nilai sebagai

1) Minat Belajar terhadap prestasi belajar PAI

a) Nilai korelasi sebesar 0,239 yang berarti hubungannya rendah yang artinya tidak terdapat hubungan minat belajar terhadap prestasi belajar PAI.

b) Adapun besarnya nilai Sig. yaitu $0,43>0,05$ artinya tidak terdapat hubungan antara minat belajar terhadap prestasi belajar PAI.
2) Kedisiplinan terhadap prestasi belajar PAI

a) Nilai korelasi sebesar 1 yang berarti hubungannya sangat kuat yang artinya terdapat hubungan minat belajar terhadap prestasi belajar PAI.

b) Adapun besarnya nilai Sig. yaitu $0,07>0,05$ artinya tidak terdapat hubungan antara minat belajar terhadap prestasi belajar PAI.

Adapun untuk mengetahui hasil regresi ganda, maka diperoleh output melalui aplikas IBM SPSS 21, adalah sebagai berikut. 
Tabel 8. Uji Signifikansi Persamaan Regresi

\begin{tabular}{|l|r|r|r|r|r|}
\hline \multicolumn{1}{|c|}{ ANOVA $^{\mathbf{a}}$} \\
\hline Model & Sum of Squares & df & $\begin{array}{c}\text { Mean } \\
\text { Square }\end{array}$ & F & Sig. \\
\hline Regression & .438 & 2 & .219 & 3.899 & $.023^{\mathrm{b}}$ \\
Residual & 6.913 & 123 & .056 & & \\
Total & 7.352 & 125 & & & \\
\hline
\end{tabular}

a. Dependent Variable: Prestasi Belajar PAI

b. Predictors: (Constant), Kedisiplinan, Minat Belajar

Pada tabel 8 diatas, Nilai Sig. 0,23 $>0,05$ yang menandakan bahwa variabel $X_{1}, X_{2}$, tidak berpengaruh terhadap Y, dan hal ini menandakan persamaan regresinya adalah tidak signifikan.
Untuk mengetahui besarnya derajat keberpengaruhan variabel $X_{1}, X_{2}$ yaitu pemahaman terhadap variabel $Y$, yaitu pengamalan. Maka, melalui aplikasi IBM SPSS 21 diperoleh hasil sebagai berikut:

Tabel 9. Hasil Koefisien Korelasi

Model Summary

\begin{tabular}{|l|r|r|r|r|}
\hline Model & \multicolumn{1}{|c|}{$\mathrm{R}$} & R Square & $\begin{array}{c}\text { Adjusted R } \\
\text { Square }\end{array}$ & $\begin{array}{r}\text { Std. Error of } \\
\text { the Estimate }\end{array}$ \\
\hline 1 & $.244^{\mathrm{a}}$ & .060 & .044 & .23708 \\
\hline
\end{tabular}

a. Predictors: (Constant), Kedisiplinan, Minat Belajar 
Diperoleh $\mathrm{R}=0,244$. Maka, koefisien determinasi diperoleh dengan rumus:

$$
\begin{aligned}
& \mathrm{KD}=r^{2} \times 100 \% \\
& \mathrm{KD}=(0,244)^{2} \times 100 \% \\
& \mathrm{KD}=5,95 \%
\end{aligned}
$$

Berdasarkan data tersebut, dapat diketahui bahwa koefisien determinasi sebesar $5,95 \%$ dimana tingkat keterpengaruhan minat belajar dan kedisiplinan terhadap prestasi belajar PAI siswa sangat rendah. Maka selebihnya $94,05 \%(100 \%-5,95 \%=94,05 \%)$ prestasi belajar PAI siswa kelas XI SMAN 7 Bandung dipengaruhi oleh faktor lain yang tidak diuraikan dalam penelitian ini.

\section{KESIMPULAN}

Berdasarkan penelitian yang telah dilakukan, maka dapat ditarik kesimpulan sebagai berikut:

1. Minat belajar PAI pada siswa kelas XI di SMAN 7 Bandung mayoritas termasuk dalam kategori tinggi. Hal ini dibuktikan dari hasil penelitian bahwa responden yang memiliki minat belajar yang tinggi yaitu sebanyak 79 orang atau 92\% dari seluruh sampel. Sedangkan sisanya yaitu sebanyak 7 orang atau $8 \%$ dari seluruh sampel memiliki minat belajar yang rendah.

2. Kedisiplinan siswa kelas XI di SMAN 7 Bandung mayoritas termasuk dalam kategori sedang. Hal ini dibuktikan dari hasil penelitian bahwa responden yang berdisiplin tinggi yaitu sebanyak 53 orang atau $24 \%$ dari seluruh sampel. Sedangkan responden yang berdisiplin sedang yaitu sebanyak 73 orang atau 58\% dari seluruh sampel.

3. Prestasi belajar PAI pada siswa kelas XI di SMAN 7 Bandung mayoritas termasuk dalam kategori tinggi. Hal ini dibuktikan dari nilai rapot siswa bahwa mayoritas semua siswa kelas XI SMAN 7 Bandung tuntas dalam mata pelajaran PAI dan budi pekerti, dan hanya satu siswa kelas XI SMAN
7 Bandung tidak tuntas dalam mata pelajaran PAI dan budi pekerti.

4. Tidak terdapat pengaruh signifikan minat belajar secara parsial terhadap prestasi belajar PAI pada siswa kelas XI di SMAN 7 Bandung. Hal ini dibuktikan dari hasil penelitian bahwa berdasarkan pengujian melalui statistik-t, Nilai $\mathrm{t}$ hitung adalah sebesar 0,577, sementara $t$ tabel diperoleh dari $\mathrm{dk}=\mathrm{n}-2 \quad(126-2=124)$ dengan taraf signifikansi 5\%, karena $t_{\text {hitung }}<t_{\text {tabel }}(0,577<1,960)$. Maka Ho diterima artinya tidak terdapat hubungan yang signifikan antara minat belajar terhadap prestasi belajar PAI siswa kelas XI SMAN 7 Bandung.

5. Tidak terdapat pengaruh signifikan kedisiplinan secara parsial terhadap prestasi belajar PAI pada siswa kelas XI di SMAN 7 Bandung. Hal ini dibuktikan dari hasil penelitian bahwa berdasarkan pengujian melalui statistik-t, Nilai $\mathrm{t}$ hitung adalah sebesar 1,876, sementara $t$ tabel diperoleh dari $\mathrm{dk}=\mathrm{n}-2 \quad(126-2=124)$ dengan taraf signifikansi 5\%, karena $t_{\text {hitung }}<t_{\text {tabel }}(1,876<1,960)$. Maka Ho diterima artinya tidak terdapat hubungan yang signifikan antara kedisiplinan terhadap prestasi belajar PAI siswa kelas XI SMAN 7 Bandung.

6. Terdapat pengaruh minat belajar dan kedisiplinan secara simultan terhadap prestasi belajar PAI pada siswa kelas XI di SMAN 7 Bandung sebesar $5,95 \%$, dan sisanya sebesar $94,05 \%$ dipengaruhi oleh variabel lainnya yang tidak diamati di dalam penelitian ini. Hal ini dibuktikan dari nilai nilai $\mathrm{R}$ sebesar 0,244.

Dengannya, penulis ingin menyampaikan beberapa rekomendasi sebagai berikut:

1. Bagi Sekolah

Hasil penelitian yang telah dilakukan oleh peneliti, bahwa minat 
belajar, kedisiplinan, dan prestasi belajar PAI siswa kelas XI termasuk kategori tinggi. Peneliti merekomendasikan bagi SMA Negeri 7 Bandung untuk lebih ditingkatkan lagi membangun minat belajar dan kedisiplinan siswa guna meningkatkan prestasi belajar. Hal ini sesuai dengan visi yang dijadikan oleh SMA Negeri 7 Bandung pada poin kedua dan ketiga, yaitu berbudaya lingkungan dan berprestasi sehingga lingkungan yang ada di sekolah menunjang pembelajaran dan meningkatkan minat belajar siswa sehingga prestasi belajar siswa tinggi.

\section{Bagi Guru PAI}

Peneliti merekomendasikan kepada guru PAI, hendaknya Guru PAI dapat meningkatkan minat belajar dan kedisiplinan siswa sehingga dalam setiap tujuan pembelajaran dapat tercapai sehingga meningkatkan prestasi belajar siswa. Perlu peningkatan kegiatan pembelajaran mengajar (KBM). PAI/Islam telah mengajarkan umatnya untuk belajar, berprestasi, dan disiplin. Semestinya PAI memberikan motivasi yang tinggi terhadap perolehan prestasi belajar dan kedisiplinan siswa. Saran bagaimana meningkatkan semangat belajar PAI yang memberikan dampak positif terhadap peningkatan prestasi belajar salah satunya dengan menggunakan metode yang tepat. Metode juga perlu diperhatikan dalam aspek pembelajaran di kelas. Salah satu metode untuk menanamkan nilai-nilai pendidikan yaitu menggunakan metode Qurani (metode amtsal, metode kisah Qurani, metode Ibrah Mauidzoh, metode targibtarhib, metode tajribi, metode uswah hasanah, dan metode hiwar hawari) karena dalam metode Qurani dikembangkan aspek akal, perasaan, keterampilan, maupun aspek-aspek kemanusiaan lainnya. Kegiatan pembelajaran lainnya yang menunjang keterampilan membaca AlQur'an siswa, guru bisa mengalokasikan waktu 10 menit untuk membimbing siswa membaca Al-Qur'an sebelum pembelajaran di mulai.
3. Wakil Kepala Sekolah Bidang Kesiswaan/Kurikulum

Peneliti merekomendasikan kepada wakil kepala sekolah bidang kesiswaan untuk terus meningkatkan kedisiplinan siswa dan membangun lingkungan sekolah yang menunjang kegiatan pembelajaran. Sedangkan untuk wakil kepala sekolah dapat membuat kurikulum sebelum belajar, dimana kegiatan didalamnya terdapat budaya cinta Ilahi dengan mengamalkan membaca AL-Qur'an, shalat dhuha dan shalat dzuhur berjama'ah dalam rangka membiasakan membaca Al-Quran dan menanamkan nilai-nilai shalat dalam kehidupan sehari-hari.

\section{Bagi Siswa}

Peneliti merekomendasikan kepada siswa untuk membaca pelajaran sebelum kegiatan belajar mengajar (KBM) guna mendapat manfaat dari setiap pembelajaran dan meningkatkan minat belajar siswa khususnya minat baca siswa.

5. Peneliti Selanjutnya

Peneliti merekomendasikan kepada peneliti selanjutnya untuk membaca teori yang relevan dengan variabel sehingga memudahkan membuat instrumen dan memperhatikan kalimat atau konstruk yang sesuai dan mudah dipahami sehingga tidak mempunyai makna ganda dalam setiap itemnya.

\section{DAFTAR PUSTAKA}

Undang-Undang Sistem Pendidikan Nasional Nomor 20 tahun 2003

Arifin, Z. (2012). Evaluasi Pembelajaran Prinsip, Teknik, Prosedur (4 ed.). Bandung: PT. Remaja Rosdakarya. Dalyono, M. (2009). Psikologi Pendidikan (5 ed.). Jakarta: PT. Rineka Cipta.

Hadis, A. (2008). Psikologi dalam Pendidikan (2 ed.). Bandung: CV. Alfabeta.

Hurlock, E. B. (1978). Child Development Sixth Edition. (M. Tjandrasa, Penerj.) Jakarta: Erlangga. 
Kebudayaan, K. P. (2013). Pedoman Penelusuran Minat Peserta Didik Sekolah Menengah Pertama. Jakarta: Direktorat Pembinaan Sekolah Menengah Pertama.

Majid, A. (2012). Belajar dan Pembelajaran Pendidikan Agama Islam (1 ed.). Bandung: PT Remaja Rosdakarya.

Majid, A., \& Andayani, D. (2006). Pendidikan Agama Islam Berbasis Kompetensi (Konsep dan Implementasi Kurikulum 2004) (3 ed.). Bandung: PT Remaja Rosdakarya.

Majid, A., \& Andayani, D. (2012). Pendidikan Karakter Perspektif Islam (2 ed.). Bandung: PT. Remaja Rosdakarya.

Mulyasa, E. (2010). Kurikulum Berbasis Kompetensi Konsep, Karakteristik, dan Inovasi (12 ed.). Bandung: PT. Remaja Rosdakarya.

Slameto. (2003). Belajar dan FaktorFaktor yang Mempengaruhinya (4 ed.). Jakarta: PT Rineka Cipta.

Syah, M. (2011). Psikologi Pendidikan dengan Pendekatan Baru (17 ed.). Bandung: PT Remaja Rosdakarya.

Syahidin. (2009). Menelusuri Metode Pendidikan dalam Al-Qur'an (1 ed.). Bandung: CV. Alfabeta.

Yusuf, S., \& Sugandhi, N. M. (2011). Perkembangan Peserta Didik. Jakarta: PT. RajaGrafindo. 